\title{
Doświadczenia uczestnictwa w mediach społecznościowych osób konsekrowanych
}

Bardzo rzadko zdarza się, by aktywność w mediach społecznościowych traktować i badać z perspektywy doświadczenia komunikacyjnego. W rozlicznych badaniach naukowych i motywowanych monitoringiem mediów badacze zwykle starają się dociekać, jakie narzędzia są skuteczne w budowaniu wizerunku marki (produktowej lub osobistej), jak realizuje się konstruowanie komunikacji, budowanie wizerunku, jego korygowanie lub zmiana. Liczne teksty dowodzą, jakie narzędzia, techniki i scenariusze są skuteczne w zarządzaniu sytuacją kryzysu informacyjnego lub wizerunkowego. Znajdziemy wiele przykładów analiz indywidualnych: blogerów, celebrytów, dziennikarzy internetowych. Zetkniemy się też z licznymi badaniami dotyczącymi wpływu nowych kanałów komunikacji na obyczaje komunikacyjne, aksjologie komunikacji i przemiany antropologiczne w kontekście medialnym.

Moje badanie ankietowe, którego wyniki zostaną przedstawione w niniejszym tekście, miało nieco inne cele. Postanowiłem skupić się na dość specyficznej (ale łatwej w doborze składu respondentów badanych i ich wstępnej selekcji) grupie uczestników aktywności komunikacyjnych w mediach społecznościowych, jaką są osoby konsekrowane ${ }^{1}$. Tak się złożyło, że w badaniu brały udział wyłącznie osoby związane z Kościołem katolickim w Polsce (co może mieć znaczenie dla uzyskanych wyników). Zależało mi na tym, by poprzez dotarcie do reprezentantów środowiska duchownych uzyskać dane odnośnie do tego, jakie są autentyczne, osobiste doświadczenia z zarządzaniem personalnym profilem w mediach społecznościowych, aktywnością blo-

${ }^{1} \mathrm{~W}$ badaniu brały udział osoby konsekrowane - duchowni zakonni oraz zakonnice, reprezentujący zakony i zgromadzenia zakonne działające w Polsce. 
gerską lub prowadzeniem profilu instytucjonalnego zakonu, zgromadzenia lub domu (konwentu) zakonnego.

Jak słusznie pisał Jerzy Jastrzębski:

Trudność badań nad wzajemnymi powiązaniami mediów i religii powiększa dodatkowo kategorialna różnica praktyk społecznych i organizujących je instytucji. Potrójna natura mediów jako technicznego przekaźnika, politycznego gracza i potężnego aktora gospodarczego, podobnie jak wielość i złożoność ról Kościoła, sprawia, iż pogodzenie czy choćby uwzględnienie misji i interesów obu podmiotów wymaga zabiegów, których rezultaty są nieprzewidywalne i trudne do uchwycenia ${ }^{2}$.

Trudno jednoznacznie stwierdzić, czy uzyskany w sondażowym badaniu odsetek odpowiedzi jest jakkolwiek satysfakcjonujący. Nie mam dostępu do żadnych danych, które wskazywałyby, jaki jest procent osób duchownych, które są aktywne w sieci, czy jaki jest stan liczbowy osób duchownych, które posługują się kontami w portalach społecznościowych. Jeśli założymy, że jest to aktywność powszechna, można przyjąć, że moje badanie ma charakter ograniczony, jednak sondażowo pokazuje pewne prawidłowości ${ }^{3}$.

Wykorzystanie mediów, w tym mediów społecznościowych, w kontekście komunikacji konfesyjnej jest niezwykle inspirujące i intrygujące. Pojawiają się w nim bowiem liczne pytania i wątpliwości. Pierwszą jest zapewne nieufność, z jaką instytucja Kościoła podchodzi do mediów. Jest ona łagodzona dokumentami urzędu nauczycielskiego oraz przemianami w aktywności duszpasterskiej, ale zmiany te dotyczą jednak przede wszystkim instytucji, wypowiedzi oficjalnych, intencjonalnego wytyczania dróg rozwoju, a nie poszczególnych osób duchownych i prywatnych opinii.

Bardzo intensywnie tematykę mediów i komunikacji w świecie społeczności sieciowych eksponował w swoich wystąpieniach Benedykt XVI. Odnosił się on do kategorii wartości, prawdy, dialogu, kwestii związanych z budowaniem relacji i wartości „przyjaźni”, o której w kontekście zapośredniczania przez relacje cyfrowe i jednocześnie w odniesieniu do duszpasterstwa pisał:

pojęcie przyjaźni jest bardzo często używane w słownictwie serwisów społecznościowych, jakie pojawiły się w ostatnich latach. Pojęcie to jest jedną z najszlachetniejszych zdobyczy ludzkiej kultury. W przyjaźni i poprzez przyjaźń wzrastamy i rozwijamy się jako istoty ludzkie. [...] Kiedy bowiem pragnienie wirtualnej łączności staje się obsesją, człowiek zaczyna się izolować, zrywając realne więzi społeczne ${ }^{4}$.

2 J. Jastrzębski, Media i religia, [w:] Media a religia, red. I. Borkowski, B. Jastrzębski, D. Lewiński, Wrocław 2011, s. 18.

${ }^{3} \mathrm{~W}$ pewnym stopniu przedstawione wyniki korespondują z cyklem badawczym zapoczątkowanym sondażem i powstałym na ich bazie tekstem: Relacje z mediami i dziennikarzami w ocenie przedstawicieli Kościołów i związków wyznaniowych zarejestrowanych w Rzeczpospolitej Polskiej, który opublikowałem $\mathrm{w}$ tomie Media a religia (s. 61-78).

${ }^{4}$ M. Laskowska, K. Marcyński SAC, Komunikacja społeczna według Benedykta XVI, Kraków 2016, s. 43. 
Jak widzimy, nauczanie papieskie ma tu jednak wciąż charakter ambiwalentny docenia się aktywność komunikacyjną w social mediach, lecz także wskazuje się na zagrożenia, które są z nią związane. Kategoria umiaru, przećwiczona w życiu zakonnym, jest tu wciąż chyba terra incognita. Zapewne dodatkowo pojawiają się - już na poziomie szczegółów, podejmowania realnych decyzji komunikacyjnych przez nadawcę - liczne pytania i wątpliwości, np. takie jak: jaki status można sobie nadać?; jak można komunikować, by nie narazić się na konsekwencje karne czy to o charakterze dyscyplinarnym, związane z głoszeniem poglądów niezgodnych z nauczaniem Kościoła, czy stanowiskiem ideologicznym części jego reprezentantów w Polsce ${ }^{5}$, czy też z wątpliwościami, które budzi sama obecność i aktywność w mediach (w tym $\mathrm{w}$ mediach społecznościowych)?

Bardzo ważna wydaje się kategoria instytucjonalna: czy nadawca wskazujący na swoje związki formalne z instytucją Kościoła (inkardynowany do konkretnej diecezji ksiądz, członek lub członkini zakonu czy zgromadzenia zakonnego) reprezentuje siebie czy wspólnotę (instytucję Kościoła, diecezję, zakon, zgromadzenie zakonne). Czy aktywność w sieci, w której wyraźnie sygnalizuje się swoją przynależność do stanu duchownego (poprzez określenia nominatywne „ksiądz”, „ojciec”, „brat”, „siostra”) lub poprzez komunikację symboliczną (np. umieszczanie zdjęć w stroju duchownym bez sygnałów dystansu, które wskazywałyby na imitację przynależności do stanu duchownego ${ }^{6}$ ), jest aktywnością prywatną czy instytucjonalną? Czy kryzysy wizerunkowe lub zwykłe wchodzenie w relacje komunikacyjne z innymi użytkownikami sieci ma charakter prywatny czy publiczny, czy angażuje poszczególne osoby jako takie, czy też od razu nakłada na nie obowiązki reprezentowania zarówno siebie jako osoby, jak i instytucji i kompleksu wartości, które uznało się za życiowy drogowskaz?

Zainteresowanie aktywnością komunikacyjną duchownych w mediach społecznościowych może się wydawać nieuzasadnione. Selekcjonuje się grupę, która formalnie ma taki sam status jak każda inna w przestrzeni medialnej, podejmuje takie same działania, liczy na nawiązanie i podtrzymanie kontaktu, na perswazyjne przekazanie treści, na których jej zależy, stara się budować własny pozytywny wizerunek czy wchodzić $\mathrm{w}$ dialog $\mathrm{z}$ otoczeniem. Tu jednak pojawia się dość istotna wartość dodana - duchowni, o ile pod uwagę bierzemy profile o realnej charakterystyce, wchodzą w odmienny od standardowego kontakt. Podejmują go bowiem zwykle w sposób, który odsyła do sfery ideologii i wartości, a z drugiej jednoznacznie przypisuje nadawcę do kontekstu o charakterze instytucjonalnym. Nakłada na niego zobowiązania, takie jak podejmowanie polemiki z adwersarzami, przekaz treści i po-

${ }^{5}$ Np. problemy o. Pawła Gużyńskiego OP w związku z jego aktywnością w mediach społecznościowych i na tej podstawie podejmowanych przez przełożonych działań wyjaśniających; https://dominikanie.pl/2017/09/oswiadczenie-prowincjala/ (dostęp: 2.11.2017).

${ }^{6}$ Osoby konsekrowane wraz z przyjęciem stroju duchownego biorą na siebie zobowiązania dotyczące jego używania, zostają zapoznane z uregulowaniami prawa wewnętrznego odnośnie do noszenia stroju zakonnego, szacunku dla niego oraz symboliki, którą ewokuje. 
staw zgodnych z doktryną reprezentowanej organizacji, poddawanie się (formalne lub wyłącznie zinternalizowane jako autokontrola) nadzorowi władz zwierzchnich i branie pod uwagę ewentualnych konsekwencji swoich niestandardowych działań komunikacyjnych, przyjmowania postaw lub komunikowania treści nieortodoksyjnych. Wszystko to jest istotne, gdy odbiorca treści medialnych staje wobec zróżnicowanego przekazu, który musi nie tylko aktywnie percypować, lecz także umiejętnie interpretować. W kontekście duszpasterskim czy pewnego typu duszpasterstwa mediów zauważa się ten problem od lat:

Im więcej będzie Internetu (a zdajemy sobie sprawę z tego, że tak właśnie będzie się działo), tym bardziej ludzie będą sobie cenić bezpośredni kontakt z innym człowiekiem. Sieć nie jest globalną wioską, lecz środowiskiem, które daje szanse rozkwitu wielu wioskom ${ }^{7}$.

Tego typu pozycjonowanie nadawcy w sferze komunikacji prywatnej i oficjalnej, jednostkowej i instytucjonalnej jest niezwykle ciekawym polem obserwacji i dociekań $^{8}$. Nadawcy trafiają w mediach społecznościowych $\mathrm{z}$ jednej strony na wyzwania związane z kontrolą swojego wizerunku, komfortu psychicznego i zabezpieczania sfery bezpieczeństwa emocjonalnego, $\mathrm{z}$ drugiej są wciąż poddawani mentalnej presji, by wychodzić ku tym, którzy są wyznawcami innych skali wartości, tych, którzy nie podzielają wiary w Boga, kodeksu moralności chrześcijańskiej lub po prostu w sposób agresywny reagują na obecność osób duchownych w przestrzeni medialnej lub na komunikowanie treści konfesyjnych.

Bardzo istotne jest również rozpatrzenie statusu i pozycji nadawcy, który występuje w specyficznych rolach: jest osobą prywatną, lecz także reprezentuje instytucję; jest sobą, ale też zaciąga w komunikacji zobowiązania do reprezentowania również pewnej regularności odnoszącej się do wartości, doktryny, stanowisk (zarówno tylko o charakterze teologicznym, doktrynalnym, jak i społecznym, politycznym, ideologicznym i ideowym).

Przedstawiane przeze mnie wyniki analizy są w zrozumiały sposób skażone niemiarodajnością. Trudno byłoby jednak przeprowadzić badanie, które mogłoby pokazać taki przekrój uczestników komunikacji społecznościowej, który można byłoby uznać za wystandaryzowany, a badaną grupę za realnie oddającą reprezentatywnie zjawiska zachodzące $\mathrm{w}$ społeczności duchownych - uczestników komunikacji w mediach społecznościowych.

Badanie dotyczy wyłącznie osób konsekrowanych, które - jak wspomniałem reprezentują Kościół katolicki. Wśród 67 respondentek i respondentów znalazło się 13 mężczyzn i 54 kobiety. To znamienne, choć biorę pod uwagę, że dobór próby był

7 T. Zasępa, Media. Człowiek. Społeczeństwo. Doświadczenia europejsko-amerykańskie, Częstochowa 2000, s. 265.

${ }^{8}$ Szerzej zob. I. Borkowski, Public relations jako zbiór środków bogatych w Kościele środków ubogich, czyli o przeszkodach w rozwoju public relations instytucji konfesyjnych, [w:] Public relations. Nowe trendy, red. K. Stasiuk-Krajewska, Z. Chmielewski, D. Tworzydło, Rzeszów 2013, s. 61-78. 
losowy i trudno upatrywać tu miarodajności oraz odzwierciedlenia realnej aktywności w mediach społecznościowych dla kategorii płci. Wydaje się jednak — w związku z tym, że ankieta docierała nie tylko bezpośrednio, lecz także pośrednio do potencjalnych respondentów ${ }^{9}-$ iż sumaryczna przewaga zakonnic nad zakonnikami daje podstawy, by mówić o zróżnicowanej aktywności w social mediach.

Zdecydowana większość respondentów (53 osoby) swoje działania w mediach społecznościowych prowadzi co najmniej trzy lata, tylko 2 osoby to nowicjusze w przestrzeni Internetu. Uzyskane odpowiedzi możemy więc realnie traktować jako takie, które mają odniesienie do własnych doświadczeń, nie są jednorazowe, w jakimś stopniu są już oddalone od pierwotnych emocji - entuzjazmu związanego z tym, że odkryło się nową, wcześniej nieznaną przestrzeń komunikacji, lub pełnego negatywnych nastawień zbioru uprzedzeń wynikających z poznawania nowej i obcej przestrzeni.

Te postawy wpisują się w świadomość urzędu nauczycielskiego Kościoła, który od pewnego czasu ma na uwadze aktywność duszpasterską w mediach społecznościowych, umiejętnie i konsekwentnie poucza o postawach, które powinni w nich przyjmować duchowni.

Rozpowszechniona multimedialność i bogactwo „opcji menu” tejże komunikacji mogą jednak stwarzać ryzyko, że wykorzystanie jej będzie podyktowane samą potrzebą zaistnienia i błędnym postrzeganiem Sieci wyłącznie jako terytorium, które trzeba zająć. Od księży natomiast wymaga się, by potrafili być obecni w świecie cyfrowym w sposób zawsze wierny przesłaniu ewangelicznemu, by odgrywali właściwą sobie rolę animatorów wspólnot, które w dzisiejszych czasach coraz częściej wyrażają się poprzez różnorodne „głosy”, pochodzące ze świata cyfrowego

— pisał już w 2010 r. Benedykt XVI ${ }^{10}$. W podobnym duchu wypowiada się (aczkolwiek wypowiedzi dowodnie wspiera własną aktywnością w sieci) papież Franciszek ${ }^{11}$.

Co ciekawe, w przeważającej większości badani wskazywali, że ich działalność w Internecie jest sprywatyzowana i nie podlega kontroli ze strony przełożonych (56 osób). Nie chodzi tu tylko o kwestię formalną związaną z tym, czy występuje się w roli reprezentanta wspólnoty, specjalisty do spraw zarządzania komunikacją czy PR-owca. W wielu wypadkach badani prowadzą bowiem aktywność w sieci, zapośredniczając dane odnoszące ich osoby jednoznacznie do instytucji, w których są formalnie zako-

${ }^{9}$ Przygotowana przeze mnie ankieta była rozsyłana wraz z listem wyjaśniającym z mojego konta na portalu Facebook do właścicieli kont osobistych i/lub instytucjonalnych osób duchownych, a następnie - częściowo dzięki wsparciu osób duchownych - przekazywana kolejnym osobom konsekrowanym, które są aktywne w social mediach.

${ }^{10}$ M. Laskowska, K. Marcyński SAC, op. cit., s. 46.

11 „To jest to właśnie: tworzenie Kościoła w drodze. Wyzwanie! Doprowadzenie do odkrycia, nie tylko dzięki spotkaniu osobowemu, ale również poprzez środki społecznego przekazu piękna tego wszystkiego, co jest u podstaw naszej drogi i naszego życia, piękna, wiary, piękna spotkania z Chrystusem. Także w kontekście komunikacji” - Franciszek, Trzeba towarzyszyć człowiekowi w epoce cyfrowej. Audiencja dla uczestników zgromadzenia plenarnego Papieskiej Rady ds. Środków Społecznego Przekazu (21.09.2013), „L'Osservatore Romano” 11, 2013, s. 39. 
twiczeni (zgromadzenia zakonne, instytuty świeckie, zakony mnisze). Mimo to nie następuje w odniesieniu do tej aktywności, publikowanych treści czy prezentowanych komunikatów o charakterze repostowania kontrola ze strony przełożonych zakonnych. Nie chciałbym tu przesądzać, być może jest to wynik zaufania czy uznania, że sieć jest przestrzenią sprywatyzowaną, a nie oficjalną, a więc podejmowane tam działania lub publikowane treści nie mają charakteru publicznego, być może aktywność ta nie jest objęta nadzorem oficjalnym, zinstytucjonalizowanym (trudno chyba przyjąć, że przełożeni nie zdają sobie sprawy z tego, kto i jakiego typu aktywności w mediach elektronicznych podejmuje, jeśli zakładamy, jak to było w tym badaniu, że dane samoopisowe jednoznacznie wskazują na zakonną afiliację podmiotu).

Zdecydowana większość badanych (50 respondentów) podjęła aktywność w mediach społecznościowych już jako osoba konsekrowana (to zapewne w większości wypadków internetowi migranci), podczas gdy 11 osób kontynuuje aktywność w sieci zapoczątkowaną przed wstąpieniem do zgromadzenia lub zakonu. Co istotne, 6 osób wskazało, że aktywność komunikacyjną w mediach społecznościowych prowadziły przed wstąpieniem, na czas formacji ją zawiesiły, a następnie wznowiły już jako osoby konsekrowane. Wydaje się to warte podkreślenia, gdyż wskazuje na pewną świadomość wagi relacji, które nawiązuje się i podtrzymuje sieciowo. Nie wiem, w jakim stopniu na owo zawieszenie aktywności wpłynęło formalne odcięcie dostępu do Internetu, na ile było ono świadomym wyborem, czy też na ile było wymogiem, który został postawiony przez wychowawców zakonnych. Ale jeśli pewnym standardem zapisanym w zwyczajnikach regulujących codzienność życia zakonnego jest zapis dotyczący ograniczenia kontaktów osób w czasie formacji z otoczeniem zewnętrznym, wymogów stawianych wobec kontaktów z rodziną, znajomymi, nierzadko także ze wspólnotą zakonną jako taką, to można zakładać, że wygaszanie aktywności w mediach społecznościowych również jest jakimś narzędziem formacyjnym, służy uświadomieniu wagi czasu refleksji, przemiany, zwrócenia się raczej ku swojemu wnętrzu niż ku relacjom ze światem zewnętrznym. Ten swoisty komunikacyjny post wydaje się niezwykle intrygujący.

Wyniki badania wskazują, że respondenci to osoby, które prowadzą zróżnicowaną aktywność sieciową, w przeważającej większości spersonalizowaną - są one obecne pod swoimi danymi personalnymi na Facebooku (60), są aktywne na Instagramie (9) oraz Snapchacie (1); 8 respondentów prowadzi aktywność sieciową wyłącznie instytucjonalnie, prowadząc media społecznościowe zgromadzenia (dane nie sumują się do $100 \%)$.

Internetowa aktywność badanych nie polega w większości na prowadzeniu bloga (tylko realizowaniu innych aktywności w mediach społecznościowych). Co ciekawe, poza 50 wskazaniami negatywnymi (w sieci funkcjonuję, prowadząc bloga) 9 osób prowadzi bloga wspólnoty zakonnej, do której należy, 7 - bloga prywatnego, 6 - bloga instytucjonalnego, a 5 - profesjonalnego, co zostało $\mathrm{w}$ ankiecie sprecyzowane jako blog, który charakteryzuje się zwartą tematyką, ma charakter jednoznacznie odnoszą- 
cych się do statusu osoby duchownej, a więc związany jest z tematyką powołaniową, teologią duchowości, teologią życia zakonnego, duszpasterstwem oraz katechetyką.

Większość respondentów (32) to osoby, które w przestrzeni komunikacji społecznościowej używają podwójnych danych osobowych: zakonnych i świeckich, co rozumiem tutaj jako taką konstrukcję nazwy profilu lub takie w nim udostępnione dane, które wskazują na imię (urzędowe), imię (zakonne) oraz nazwisko. Niemniej aż 17 osób funkcjonuje, legitymując się wyłącznie danymi świeckimi, co rozumiem tu jako imię (urzędowe) i nazwisko (urzędowe) bez określeń skrótowych (s., br., ks., o.) oraz akronimicznych (odsyłających do skrótowców wielowyrazowych nazw własnych zakonów i zgromadzeń zakonnych). Nieco mniej respondentów (14) to osoby, które w sieci posługują się wyłącznie danymi zakonnymi: imieniem (zakonnym), nazwiskiem (urzędowym) i/lub akronimem. Co znamienne, aż 11 osób (15\% respondentów) funkcjonuje w mediach społecznościowych anonimowo.

Najistotniejszymi motywami obecności i aktywności w mediach społecznościowych są: przekaz duszpasterski (dla 56 osób), przekaz informacyjny (dotyczący działalności powołaniowej; dla 47 osób) oraz podtrzymywanie kontaktów ze znajomymi spoza sieci (rozumiany tu jako relacje, które zawiązały się i na co dzień realizują się w innych przestrzeniach niż komunikacja zapośredniczona; dla 30 osób). Wśród odpowiedzi i uzasadnień powodów obecności w mediach społecznościowych znajdujemy także liczne wskazania dotyczące przekazu o charakterze informacyjnym (29 osób), który odnosi się do aktywności i działań o wydźwięku publicznym, społecznym, organizacyjnym (nie duszpasterskim lub związanym $z$ rozwojem duchowym). Dla 12 osób media społecznościowe są ponadto kanałem przekazywania informacji odnoszących się do sfery prywatnej (informowania i propagowania informacji dotyczących życia prywatnego), a dla 9 osób jest to również narzędzie podtrzymywania kontaktów z osobami, które pozostają wyłącznie znajomymi sieciowymi.

Zauważmy, że generowany w sieci ekosystem komunikacyjny mediów społecznościowych jest wykorzystywany (lub taka interpretacja nasuwa się respondentom jako intencjonalnie najważniejsza) jako narzędzie komunikacji informacyjnej, nie dialogicznej, w której komunikat generowany przez nadawcę nie jest początkiem następującego po nim łańcucha zdarzeń komunikacyjnych: konstrukcja - emisja deskrypcja, ale właśnie - przede wszystkim lub w ogóle - początkiem aktywności komunikacyjnej w sieci.

Media społeczne, jak wynika z samej definicji, znacznie lepiej niż mass media realizują ideę mediów, które dopasowują się do społecznych oczekiwań, w końcu sam proces rozprzestrzeniania informacji realizowany jest przez społeczną interakcję ${ }^{12}$.

Tu interakcja ma przede wszystkim kontekst staromedialny — relatywnie szerokiego propagowania łatwo dostępnych i tanich w dostarczeniu treści.

12 M. Nowakowska, Social media - etyka i wartość, [w:] Wartości mediów, red. I. Hofman, D. Kępa-Figura, t. 2, Lublin 2014, s. 129. 
Wchodzenie w relacje komunikacyjne zakłada wstępne podjęcie decyzji dotyczącej otwarcia na dialog. Znamienne pod tym względem wydaje się, że zdecydowana większość (61 respondentów) wskazuje, że prowadzony przez nich profil lub redagowany blog dopuszcza informację zwrotną (komentarz, kontakt, ustalenie statusu lub oceny za pomocą symboli). Rzadko w kontakt (dialogiczny) z czytelnikami bloga lub znajomymi sieciowymi wchodzi 39 respondentów, ale 19 tę aktywność podejmuje często, a tylko 9 wskazuje, że takich dialogów nigdy nie prowadzi.

Bardzo podobnie rozłożyły się odpowiedzi na pytanie odnośnie do tego, czy kontroluje się aktywność czytelników/znajomych sieciowych w social mediach. Moim zamysłem było sprawdzenie, czy taka weryfikacja w ogóle następuje, a w kolejnych pytaniach próba skłonienia respondentów do udzielenia odpowiedzi na pytania związane z korygowaniem sieci znajomych i okolicznościami, które do tego skłaniają. Odpowiedzi wydają się bardzo podobne do tych dotyczących wchodzenia w relacje komunikacyjne. Tu także 39 badanych wskazało, że rzadko zaprzątają swoją uwagę kontrolowaniem tego, co udostępniają w sieci znajomi, 17 przyznało, że czyni to często, a 11 wskazało odpowiedź „nigdy”.

Respondenci są natomiast bardzo czujni przy kompletowaniu grona znajomych. Jedynie 2 osoby wskazały, że przy przyjmowaniu zaproszeń do grona znajomych nie kontroluje profilu osoby zapraszającej, tylko przyjmuje wszystkie zaproszenia. Pozostali, w liczbie 65, zanim przyjmą ofertę, weryfikują osobę kandydata, jej poglądy, postawy, polubione treści i udostępniane materiały. Takie postępowanie jest zapewne w jakiejś mierze motywowane tym, że

ludzie mogą żyć w wielu, i to nie zawsze jednorodnych, światach komunikacyjnych. Rodzi się tutaj oczywista kwestia, na ile te światy zostają przez ludzi „obłaskawione”, uznane za własne i odczuwane jako koherentne $e^{13}$.

Niezwykle ciekawe są w mojej ocenie odpowiedzi dotyczące okoliczności i powodów usunięcia osoby z grona znajomych. Wśród możliwych odpowiedzi wskazałem kilka możliwości (odpowiedzi nie sumują się do 100\%). Zależało mi na tym, by ustalić, jakie są powody zablokowania dalszego kontaktu, lecz także jakie są przyczyny sytuacji, w której treści komunikowane nie wprost lub sygnalizowane wyłącznie pośrednio wpływają na decyzje o usunięciu z grona znajomych (a co za tym idzie - o zablokowaniu własnego dostępu do treści, których się nie pochwala). Wskazywane najczęściej motywacje potwierdzają to, co już wiadomo o internautach i podejmowanych przez nich działaniach budujących jednolity i spójny obraz świata. Nie da się tu pominąć newralgicznych w dyspucie o kształtowaniu obrazu świata przez Internet głosów krytycznych, w których na czoło wybijają się właśnie te o kształtowaniu sztucznego jednowymiarowego co do wartości i postaw świata, nakręcania spirali milczenia i społecznej niewiedzy wynikającej li tylko z progresywnego zaniżania

${ }^{13}$ M. Golka, Bariery w komunikowaniu i społeczeństwo (dez)informacyjne, Warszawa 2008, s. 31. 
stopnia samowiedzy, która miała być jedną z najistotniejszych powinności mediów wobec społeczeństw. W tym kontekście przed kilkoma laty pytanie zadawał Wojciech Orliński:

Jak potoczyłaby się afera Dreyfusa, gdyby artykuł Emila Zoli trafił tylko dreyfusardów, już i tak skądinąd przekonanych o niewinności kapitana? A trzymając się współcześniejszych przykładów: czy jeśli o kimś wiemy, że wierzy w teorie spiskowe dotyczące na przykład zamachów z 11 września, czy to będzie korzystne dla społeczeństwa, jeśli będziemy mu pokazywać wyłącznie materiały potwierdzające jego przekonania, a ukrywać przed nim wszystko to, co mogłoby zmienić jego poglądy? ${ }^{14}$

Respondenci zdecydowanie najczęściej (40 osób) wskazują, że usuwają z grona znajomych tych internautów, którzy publikują treści, co do których mają zastrzeżenia obyczajowe, emocjonalne lub ideowe. Co ciekawe, aż 20 osób podało, że blokuje dalszą komunikację z osobami, które w publikowanych materiałach lub wypowiedziach wyrażają krytyczny stosunek wobec instytucji Kościoła, a 18 osób kończy znajomość z osobami, które w prywatnych rozmowach lub prywatnych postach wyrażają krytyczny stosunek wobec duchowieństwa lub instytucji Kościoła. Nie może tu być mowy o przyjaźni trudnej, wymagającej determinacji, by relację podtrzymywać, aby ją mimo wszystko akceptować. Ta obserwacja wpisuje się w wyniki badań dotyczące np. konstruktu wyobrażeniowego odnośnie do „przyjaźni” w świecie i relacjach komunikacyjnych $\mathrm{w} \operatorname{sieci}^{15}$. Jest to $\mathrm{w}$ mojej ocenie znamienne - pokazuje wysoki odsetek osób nieodpornych zarówno na bezpośrednie, jak i pośrednie dane, postawy i zachowania krytyczne lub niezgodne z hierarchiami wartości, które wyznaje badany, a także na rozmijanie się (świadome lub nie) z tymi wskazaniami, które formułują profesjonaliści dla kreatorów marki w komunikacji ${ }^{16}$. Jeśli uznamy, że wskazania dotyczące osób, które w prywatnych wiadomościach kierowanych do respondentów wyrażają krytykę Kościoła, możemy zakładać, że respondenci stykają się z jakimś rodzajem agresji lub stalkingu w sieci. Jeśli jednak problem dotyczy biernego percypowania treści repostowanych przez innych użytkowników sieci, wtedy sprawa ma się inaczej - wydaje się, że potwierdza postawę porządkowania rzeczywistości pod względem wartości i idei, uspójniania wizji świata i jej sieciowego ujednolicania. Jest to zapewne również kwestia wstępnych założeń dotyczących obecności w social mediach. Im bardziej jest ona skoncentrowana na dawaniu świadectwa o własnym powołaniu lub na działalności o charakterze powołaniowym i/lub duszpasterskim, w tym mniejszym stopniu będzie zakładała konfliktową czy polemiczną interakcyjność. Ciekawie podsumowała tego typu perswazyjne oddziaływania w świecie analo-

14 W. Orliński, Internet. Czas się bać, Warszawa 2013, s. 73.

${ }^{15}$ Por. M. Krauz, E-przyjaźń - obraz przyjaźni i koleżeństwa w Internecie, [w:] Wspótczesne media. Medialny obraz świata, t. 2. Studium przypadku, red. I. Hofman, D. Kępa-Figura, Lublin 2015, s. 157-174.

16 Por. M. Sadowski, Rewolucja social media, Gliwice 2013, s. 63-65: Ochrona reputacji: nie ignoruj negatywów; Nie trać czasu; Nie odpowiadaj atakiem; Nie zrzucaj winy na kogoś innego. 
gowym Katarzyna Sobstyl, analizując ogłoszenia powołaniowe w prasie i budowaną w tym gatunku sytuację nadawczo-odbiorczą:

Wpływanie na zmianę postaw i sugerowanie zachowań pożądanych opiera się przede wszystkim na budowaniu wspólnego świata. Sytuacja nadawczo-odbiorcza pozwala na stworzenie atmosfery wspólnoty wynikającej z postaw chrześcijańskich. Pozwala na to także sam cel, do którego dążą uczestnicy interakcji. Adresat sięgający po ogłoszenie szuka pomocy w określeniu swojej drogi życiowej, nadawca pragnie zachęcić go do wyboru konkretnego zgromadzenia, po to, by powiększyć grono osób propagujących wartości chrześcijańskie. Wspólne działanie ma być korzystne dla obydwu stron ${ }^{17}$.

Bardzo istotne jest powiązanie tych danych z odpowiedziami, które uzyskałem na następne pytanie, dotyczące tego, czy (a jeśli tak, to czy często) respondenci spotykają się $\mathrm{w}$ sieci $\mathrm{z}$ atakami słownymi. $\mathrm{Z}$ bezpośrednimi przejawami agresji słownej w sieci nigdy nie zetknęło się 45 respondentów, rzadko ofiarami tego typu zachowań było 20 osób, a 2 spotykają się z takimi zdarzeniami często. Ze stalkingiem w sieci nigdy nie spotkało się aż 51 respondentów, a "rzadko” jako częstotliwość tego typu działań wskazało 16 osób. Podobnie w wypadku opisanym w badaniu jako agresja motywowana (uzasadniana) nie w sposób personalny czy osobisty, ale związana i uzasadniana tym, że jest się osobą duchowną, reprezentującą niejako instytucję Kościoła, z atakami słownymi spotkała się 1 osoba, 18 osób wskazało, że z tego typu zachowaniami spotyka się rzadko, zaś 48 osób udzieliło odpowiedzi przeczącej.

W kolejnych pytaniach usiłowałem ustalić, czy motywacja odnosząca się do podejmowania lub zaniechania polemiki jest związana z wartością indywidualną i merytoryczną samego krytycznego sądu, który jest formułowany przez internautę. Okazuje się, że respondenci niemal w takim samym stopniu wchodzą w polemikę, gdy sąd krytyczny dotyczy nauczania Kościoła (często taką aktywność podejmuje 10 respondentów, rzadko - 41, a nigdy - 16) oraz gdy krytyka dotyczy samej instytucji Kościoła lub duchowieństwa jako takiego (odpowiednio: 11 osób aktywnie w takie polemiki wchodzi, 40 - nigdy, a 16 - rzadko podejmuje polemikę). Wszystkie te spostrzeżenia korespondują z dostrzeganiem wyzwań dotyczących nowych struktur komunikacyjnych, które wytworzyła sieć komunikacji internetowej, w tym przede wszystkim media społecznościowe. Jak pisał Tomasz Goban-Klas:

Jakkolwiek pojawianie się nowych mediów stworzyło szanse przezwyciężenia quasi-monopolu środków masowych w dziedzinie pośredniego komunikowania społecznego, to przecież większa adresowalność nowych mediów, określania niekiedy jako tzw. narrowcasting (nadawanie wiązkowe), w odróżnieniu od broadcasting (rozsiewcze), stwarza nowe dylematy dla komunikatorów [...], pozwala na bardzo dokładną segmentację publiczności, zwracanie się do wyodrębnionych (przez nadawcę lub samych odbiorców) audytoriów ${ }^{18}$.

${ }^{17} \mathrm{~K}$. Sobstyl, „A jeżeli $i$ Ty jesteś powołany do kapłaństwa misyjnego?” - perswazyjność $i$ wartościowanie w pewnych ogłoszeniach, [w:] Teksty kultury. Oblicza komunikacji XXI wieku, red. J. Mazur, M. Rzeszutko-Iwan, t. 1, Lublin 2006, s. 235.

18 T. Goban-Klas, Media i komunikowanie masowe. Teorie i analizy prasy, radia, telewizji i Internetu, Warszawa 1999, s. 301. 
Badacze wyróżniają trzy modele obecności i aktywności komunikacyjnej reprezentantów instytucji konfesyjnych w mediach: instrumentalno-transmisyjny, ideologiczny i kulturowy. O tym ostatnim Józef Majewski pisał:

narodził się w jakiejś mierze w krytycznej reakcji na model instrumentalno-transmisyjny i model ideologiczny $[\ldots]$, widzą one religię i media jako dwa „byty” autonomiczne i niezależne ${ }^{19}$.

Dlatego też w moich dociekaniach pojawia się wiele pytań dotyczących komunikowania treści i podejmowania działań duszpasterskich łączących narzędzia komunikacji internetowej z reprezentowanymi postawami ideologicznymi.

Respondenci bardzo wysoko cenią sobie obecność i aktywność w mediach społecznościowych pod względem informacyjnym ${ }^{20}$ (przekazu dotyczącego działalności, podejmowanych inicjatyw społecznych, organizacyjnych, pomocowych): aż 46 osób wskazuje, że może przekazywać bardzo wiele (a kolejnych 14 - wiele) informacji dotyczących swojego życia jako osoby konsekrowanej. Manifestowanie obecności w mediach społecznościowych jest zbieżne z pewnym przeczuciem wyrażanym w tekstach powstałych w kręgu duszpasterskim:

Zadanie stojące przed nami w społeczeństwie mediów jest dwojakie. Po pierwsze, musimy się nauczyć, jak sobie radzić w sposób twórczy z całym bogactwem środków masowego przekazu. Po wtóre, trzeba znaleźć sposób, aby zahamować tendencje rozpadu społeczeństwa na wzajemnie nierozumiejące się grupy. Jako chrześcijanie wierzymy, iż wartości ewangeliczne powinny wypełniać wszystkie obszary życia społecznego ${ }^{21}$.

Istotna dla aktywności sieciowej osób duchownych jest także kwestia oddziaływania formacyjnego - tu 37 osób wskazało, że działania tego typu są skuteczne, 2 - że bardzo skuteczne, a 28 podało odpowiedź „trudno ocenić”. Można chyba zakładać, że jest to niejako dowód na to, jak instytucja Kościoła realizuje w ogóle swoje relacje z mediami, jak w nie wchodzi, jak z mediów poprzez swoiste podobieństwa do podstawowej narracji medialnej korzysta.

Działa tu zresztą [Kościół w mediach - I.B.] w strukturalnej zgodzie z samą medialnością; media nigdy nie przepuszczą okazji i do moralizowania, i do oferowania moralnych konfliktów, media są pełne „moralizującej gadaniny”22.

${ }^{19}$ J. Majewski, Modele rozumienia relacji religia - media, [w:] Dyskurs religijny $w$ mediach, red. D. Zdunkiewicz-Jedynak, Tarnów 2010, s. 41.

${ }^{20}$ Liczne wskazania dotyczące wagi portali społecznościowych i ich użyteczności w przekazie duszpasterskim stały się w pewnym momencie jednym z istotnych wątków nauczania Kościoła, a w dokumentach związanych np. z Dniem Środków Społecznego Przekazu - w zasadzie motywem przewodnim. Szczególnie w nauczaniu Benedykta XVI znajdziemy liczne odniesienia do kwestii uczestnictwa i aktywności w portalach społecznościowych, o których pisał, że są lub mogą być dzięki wysiłkowi ewangelizacyjnemu „portalami prawdy i wiary”, że są „nowymi przestrzeniami ewangelizacji”. Por. Orędzie na 47. Światowy Dzień Środków Społecznego Przekazu (24.01.2013).

21 T. Zasępa, op. cit., s. 279.

${ }^{22}$ D. Lewiński, Dyfuzja strukturalna a religia, [w:] Media a religia, s. 55. 
Podobnie jak wcześniej, kształtuje się tu opinia dotycząca skuteczności wykorzystania mediów społecznościowych jako narzędzia duszpasterstwa powołaniowego. Dla 33 osób jest to narzędzie skuteczne w prowadzeniu duszpasterstwa powołaniowego, dla 10 - bardzo skuteczne, podczas gdy 18 osób wskazało odpowiedź „trudno ocenić", a 6 kolejnych nie wykorzystuje mediów społecznościowych do działań w zakresie duszpasterstwa powołań.

Niezwykle istotne wydają się w omawianym badaniu oceny, które respondenci formułowali w odpowiedzi na prośbę o wskazanie trzech najistotniejszych według nich zalet aktywności w mediach społecznościowych, jaką podejmują jako osoby konsekrowane. Ta część badania wykorzystywała pytanie otwarte, respondenci odpowiadali w sposób niezwykle zróżnicowany. Część odniosła się do polecenia w sposób skonwencjonalizowany, wyliczając hasłowo trzy zalety aktywności w mediach społecznościowych, które z ich perspektywy i doświadczeń wydają się najistotniejsze. Dla części była to jednak przestrzeń wypowiedzi dłuższych, podawanych wraz $\mathrm{z}$ uzasadnieniem, komentarzem, próba zdystansowanej refleksji na temat tego, jak aktywność w mediach społecznościowych w sposób całościowy i ogarniający dotychczasowe doświadczenia przekłada się na podejmowane inne działania duszpasterskie, jak wpływa na samego piszącego, a także czym skutkuje dla kondycji wspólnoty zakonnej, którą internauci reprezentują.

Dla wielu respondentów podstawowymi wartościami, jakie wynikają z używania mediów społecznościowych, są szybkość przekazu oraz poczucie bliskości relacji między nadawcą a odbiorcą. Liczni respondenci wskazują na dialogiczność jako istotny walor obecności w mediach społecznościowych. Dzięki nim mogą nawiązywać i podtrzymywać kontakt, który w innych sytuacjach byłby przekazem jednostronnym, nastawionym na megafonowe nadawanie treści. Bardzo często zwraca się uwagę na potencjał ewangelizacyjny tych kanałów dotarcia, na niemal nieograniczone w przekonaniu piszących możliwości kreacji i wykorzystania własnej pomysłowości w propagowaniu tych treści, idei i wartości, którym się zaufało i które się w życiu realizuje. Spora grupa respondentów wskazuje, że podstawową wartością obecności w mediach społecznościowych jest szansa na poznanie nie tylko osobowe drugiego człowieka, ale przede wszystkim jego świata: wartości, stylu życia, komunikacji, języka ${ }^{23}$. Wskazuje się na lepszą orientację w problemach życiowych, które nurtują młodych ludzi. Odpowiedzi wyraźnie pokazują, że respondenci są przekonani o demograficznych wyznacznikach tego typu aktywności: social media są dla młodych, przez młodych, do młodych. W żadnej wypowiedzi nie znalazłem uwag dotyczących np. ewangelizacji osób starszych czy wchodzenia w relacje komunikacyjne nakiero-

${ }^{23}$ Tego typu refleksje pokrywają się ze wskazaniami, które wcześniej sformułowali badacze nowych mediów, wskazując na nowe doświadczenia tekstualne, nowe relacje pomiędzy podmiotami komunikacji czy sposoby dystrybucji i konsumpcji treści medialnych. Przypomniał o tym między J. Miąso, Antropologiczna powinność wobec nowych mediów i ich języka, [w:] Współczesne media. Język mediów, red. I. Hofman, D. Kempa-Figura, Lublin 2013, s. 173-190. 
wane na towarzyszenie osobom samotnym (ze względu na ograniczenia społeczne czy podeszły wiek odciętych od mobilności środowiskowej), które w sieci szukają bliższych relacji, wsparcia emocjonalnego, porady czy chęci potocznego wygadania się. W odpowiedziach pojawiają się także (choć rzadko) wskazania dotyczące odmiennej niż w kontakcie osobistym otwartości komunikacyjnej, która daje szanse do lepszego, pogłębionego kontaktu z osobami zainteresowanymi kwestiami powołaniowymi czy też takimi, które wymagają lub oczekują jakiegoś wsparcia i pomocy w sprawach duchowych. Byłoby to dowodem na trafność wcześniejszych ustaleń, które wskazują, że co prawda komunikacja internetowa sprawia pozory mniej rozbudowanej, jest aberracyjna co do formy i powstaje pod presją skrótowości, ale mimo odrzucenia całej formalnej otoczki pozwala szybciej i dokładniej wniknąć w bogactwo treści informacyjnych, które chce przekazać nadawca ${ }^{24}$. Badani podkreślają, że dzięki mediom społecznościowym możliwe jest stopniowe nawiązywanie kontaktu, że stanowią one ogniwo pośrednie - po nawiązaniu kontaktu zapośredniczonego i upływie jakiegoś czasu może dojść do kontaktu osobistego, na który na początku osoba w sieci nie jest jeszcze gotowa. Mówi się także o doświadczeniu, które nazwałbym reprezentatywnym - sama obecność w mediach społecznościowych staje się znakiem, przesłaniem, świadectwem (wiary osobistej i przynależności instytucjonalnej). Reinterpretacja tej postawy skutkuje tym, co zauważają badani: „młodzi ludzie przestają myśleć, że osoby konsekrowane to postaci z innego świata, zaczynają dostrzegać w nas ludzi". Byłaby to odpowiedź, która koresponduje z uwagami, które Benedykt XVI już przed kilkoma laty kierował do Kongregacji Edukacji Katolickiej w sprawie formacji duszpasterzy:

[Internet - I.B.] kiedy jest wykorzystywany z rozwagą, w sposób inteligentny i roztropny, stanowi narzędzie, którym można się posłużyć nie tylko w nauce, ale także w działalności duszpasterskiej przyszłych księży w różnych dziedzinach życia kościelnego, takich jak ewangelizacja, misje, katecheza, projekty edukacyjne i zarządzanie instytucjami. Także w tej dziedzinie niezwykle ważną rolę odgrywają odpowiednio przygotowani formatorzy ${ }^{25}$.

W kilku wypowiedziach jako jedna z podstawowych wartości obecności i aktywności osób konsekrowanych w mediach społecznościowych pojawia się możliwość podejmowania dyskusji z tymi, którzy krytykują instytucję Kościoła lub osoby duchowne jako takie. Jednostkowo, ale w mojej ocenie znamiennie dla kondycji badanego środowiska, pojawiają się dwie postawy. Jedna z nich ustawia na jednym poziomie przekaz religijny (duchowy) z przekazem patriotycznym, utożsamiając niejako rolę osoby duchownej z rolą krzewiciela wartości narodowych również w przestrzeni mediów społecznościowych. Druga - manifestowana kilkakrotnie - to odmawianie mediom społecznościowym racji istnienia („są niepotrzebne”) lub prezentowanie

${ }^{24}$ M. Szpunar, Rozważania na temat komunikacji internetowej, [w:] Teksty kultury..., t. 2, Lublin 2006, s. 223.

${ }^{25}$ M. Laskowska, K. Marcyński SAC, op. cit., s. 182. 
wobec nich własnej postawy emocjonalnej („nie lubię mediów społecznościowych”). Wskazania dotyczące istotności obecności osób konsekrowanych w sieci odnoszą się też do wykorzystania Internetu jako narzędzia oddziaływania organizatorskiego: organizowania zbiórek pieniężnych, poszukiwania współpracowników w różnych akcjach, kumulowania potencjału poparcia dla podejmowanych działań organizatorskich w ramach posłannictwa danego zgromadzenia czy lokalnej wspólnoty zakonnej.

Całość udzielanych odpowiedzi doskonale koresponduje z ustaleniami wieloetapowego eksperymentu badawczego, w którym Byron Reeves i Clifford Nass dowodzą tezy niby już oczywistej - traktowania mediów jako realnego gracza na scenie komunikacyjnej. Realnego, ale posiadającego argumenty, które już na starcie rywalizacji dodają pewne bonusy:

Ludzkie reakcje pokazują, że media są czymś więcej niż tylko narzędziami. Media są traktowane grzecznie, mogą wtargnąć w naszą przestrzeń osobistą, mogą posiadać osobowość, która pasuje do naszej, mogą być członkami zespołu i uaktywniać stereotypy związane z płcią. Media mogą wywoływać reakcje emocjonalne, wymagać koncentracji uwagi, zagrażać nam, wpływać na pamięć i zmieniać pojęcia tego, co naturalne. Media są pełnymi uczestnikami naszego świata społecznego i rzeczywistego ${ }^{26}$.

\section{The consecrated persons' experiences of participating in social media}

Summary

The paper is an analysis of data collected during the author's research into the consecrated persons' experiences relating to participation in social media. The author seeks to answer questions concerning the motives behind activity in social media, opinions about the effectiveness of the message, expectations and real effects of communication. The subjects are primarily members of male and female monastic orders and congregations as well as diocesan priests of the Catholic Church. The data analysis is complemented by a broader context of the functions, motives and communication activities of consecrated persons in social media.

${ }^{26}$ B. Reeves, C. Nass, Media i ludzie, przeł. H. Szczerkowska, Warszawa 2000, s. 294. 